\title{
Characterization and Classification of Soils of Bharuch Taluka in Bharuch District of Gujarat
}

\author{
Abhishek Jangir*, R. P. Sharma, G. Tiwari, B. Dash, R. K. Naitam, L. C. Malav, \\ R. Narse, N. Gautam, S. Bhure, P. Chandran and S. K. Singh \\ ICAR-National Bureau of Soil Survey and Land Use Planning, \\ Nagpur - 440 033, Maharashtra, India
}

\begin{abstract}
A detailed soil survey was undertaken at 1:10000 scale to describe, characterize, classify and evaluate the soils of Bharuch taluka, Bharuch district, Gujarat. Old and recent basaltic alluvial plains are the major landforms of the area. A total of 74 pedons, representing old (41 pedons) and recent (33 pedons) alluvial plains were studied. The soils were correlated and three soil series viz. Umraj, Derol and Singdot were identified. The Umraj belong to a very fine, smectitic Typic Haplusterts covers 30,839 ha (48.5\%) area, whereas Derol and Singdot a fine, smectitic Vertic Haplustepts and fine, mixed, Typic Haplustepts covers 20,604 ha $(32.5 \%)$ and 4,164 ha $(6.6 \%)$ area, respectively. The sand, silt and clay in the soils varied from 8 to 31,24 to 49 and 23 to 67 per cent, respectively. The soils were very deep, neutral to slightly alkaline ( $\mathrm{pH} 7.3$ to 8.4 ) with low to medium in organic carbon content $(0.14$ to $0.58 \%$ ), low to high in calcium carbonate ( 1.9 to $16.5 \%$ ) with medium to high CEC [39.4 to $\left.62.0 \mathrm{cmol}\left(\mathrm{p}^{+}\right) \mathrm{kg}^{-1}\right]$ and high base saturation (67.4 to $92.0 \%$ ). Soils were assessed as highly to moderately suitable for major crops (cotton, pigeonpea, maize, sugarcane, wheat and chickpea).
\end{abstract}

Keywords: Detailed soil survey, alluvial plain, soil classification, Vertisols, Inceptisols

\section{Introduction}

Worldwide, the demand for food commodities is expected to increase by 75-100 per cent between 20102050 (Hosain et al. 2016). At the same time, modern intensive agriculture accounted a quantum increase in the crop production and ensures food security, has also resulted in the over exploitation and degradation of natural resources such as soil, air and water in India. The declining scenario in agricultural land and the growing food demand needs attention to optimized use of soil resources. Intensive and formidable land use needs a good level of knowledge of soil resources to design

*Corresponding author :( Email: abhishekjangir1988gmail.com) suitable soil management practices (Akpan-Idiok et al. 2016).

Timely and reliable information about soil resources is very essential with regard to their nature, spatial distribution, potential and constraints. The land resource inventory process provides an insight into the potentialities and constraints for efficient management of resources. It also offers to develop appropriate information on different landform distribution, cropping pattern and soil characteristics that can be used for management and proper utilization of land resources (Manchanda et al. 2002). Sharma et al. (2018) linked the village level land resource data with climate and socio- 
economic conditions for integrated village/block development programmes in Jamnagar district of Gujarat. The systematic soil survey provides an understanding of the nature and type of soil, its limitations, potential and suitability for different land uses (Prasad et al. 2009). Moreover, a necessity is always felt for taluka-wise database to take-up various agricultural developmental programmes. Therefore, detailed soil survey (1:10000 scale) of Bharuch taluka of Bharuch district, Gujarat was carried out to characterize and classify the soils for sustainable land use planning.

\section{Materials and Methods}

Bharuch taluka is located between $21^{\circ} 25^{\prime} 13^{\prime \prime}$ to $22^{\circ} 12^{\prime} 49^{\prime \prime} \mathrm{N}$ latitude and $72^{\circ} 31^{\prime} 35^{\prime \prime}$ to $73^{\circ} 30^{\prime} 18^{\prime \prime} \mathrm{E}$ longitude in Bharuch district, Gujarat (Fig. 1) and covers an area of 63,489 ha. It belongs to the Gujarat coastal plain physiographic region and west coast plain subphysiographic region (Singh et al. 2016). It is located in Narmada river basin and mainly comprised of old and recent alluvial plains. The alluvium was derived from basaltic parent material of Amarkantak plateau, Anuppur district of Madhya Pradesh (Merh 1995). These plains are made up of a thick pile of unconsolidated sediments deposited by a combination of fluvial and aeolian agencies during the Quaternary period. The major geology is quaternary alluvium and topography is nearly level plains to very gently sloping in the north-east to south-west direction at an elevation upto $40 \mathrm{~m}$ above mean sea level (MSL).

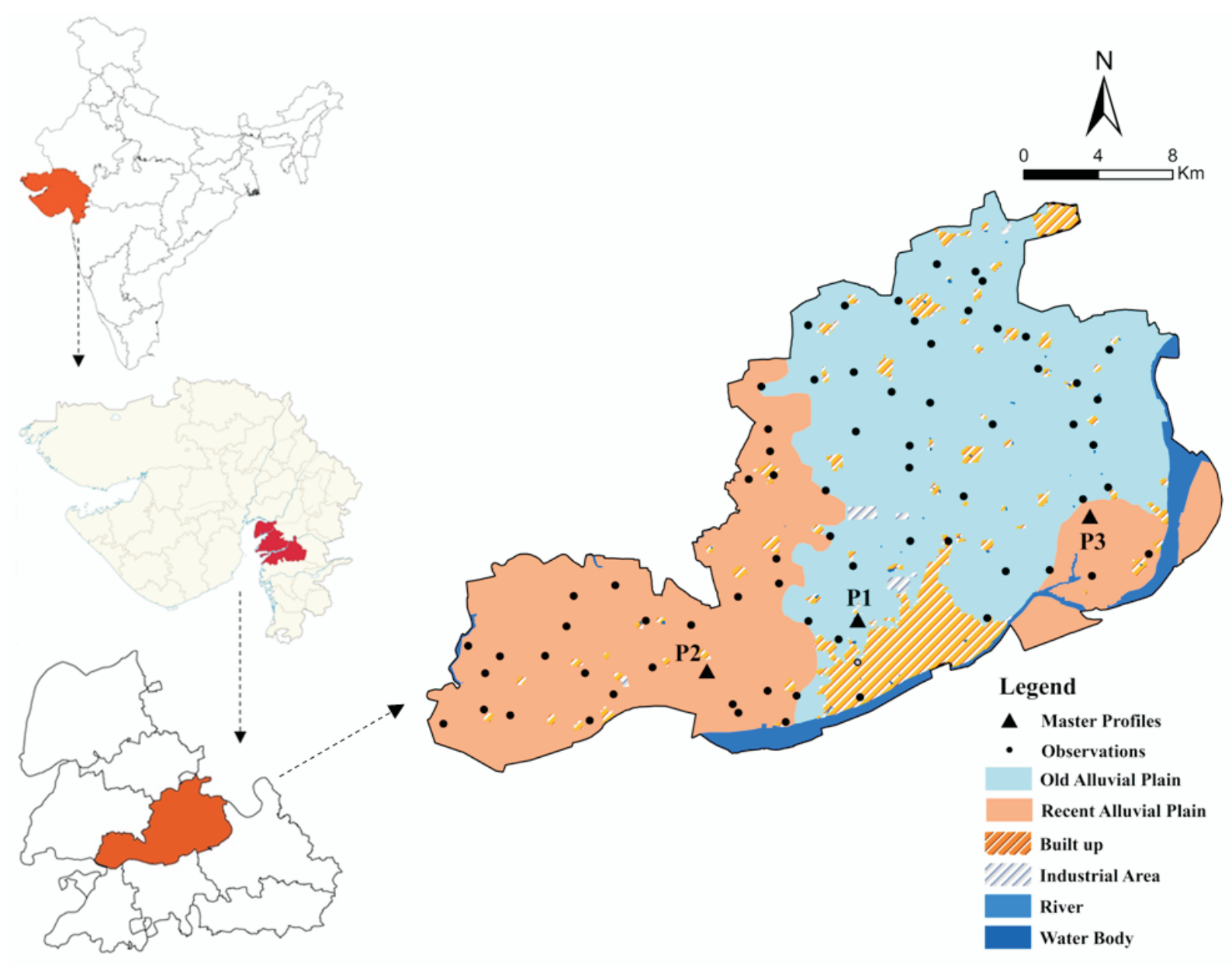

Fig. 1 Location and Landform map of Bharuch taluka with sampling sites 
The area falls under agro-ecological subregions 5.2 i.e. hot semi-arid eco-region with medium and deep black soils (Velayutham et al. 1999) and characterised by ustic soil moisture regime and hyperthermic soil temperature regime. The climate of the taluka is semi-arid with hot and moist summers and dry winters. The mean annual temperature is $27.9^{\circ} \mathrm{C}$ with mean summer temperature of $31.1^{\circ} \mathrm{C}$ and mean winter temperature $23.3^{\circ} \mathrm{C}$. May is the hottest month with $39.5^{\circ} \mathrm{C}$ mean daily maximum temperature and January is the coldest month with $12.7^{\circ} \mathrm{C}$ mean daily minimum temperature. The mean annual rainfall of the area is around $873 \mathrm{~mm}$, received mainly during the southwest monsoon from June to September. Major crops grown in this area are pigeon pea (Cajanus cajan), maize (Zea mays), cotton (Gossypium hirsutum), sugarcane (Saccharum officinarum), wheat (Triticum aestivum) and green gram (Vigna radiata) with 90 to 120 days of length of growing period (LGP). The natural vegetation of the area comprised of Azadirachta indica, Prosopis juliflora, Prosopis cineraria, Ziziphus mauritiana and Eucalyptus spp.

Detailed soil survey was carried out at 1:10000 scale with the base map prepared using Indian Remote Sensing satellite data (IRS-P6 LISS IV), Digital Elevation Models (DEM) and Survey of India (SOI) Toposheets of 1:50000 scale. The delineation of land use land cover (LULC) was carried out by visual interpretation techniques. Slope, hill shade and contour $(10 \mathrm{~m})$ maps were prepared by using Cartosat-1 DEM $(30 \mathrm{~m})$ and landform map was generated by superimposing these maps. The landform, slope and LULC were overlaid over each other in Arc-GIS to generate landscape ecological units (LEUs) map.

A total of 74 geo-referenced pedons (Fig.1) were studied for morphological properties. After correlation protocol, three series has been identified. The horizonwise soil samples from the representative soil series were collected, processed and analyzed for sand, silt and clay (Jackson 1979), saturated hydraulic conductivity
(Klute 1965), calcium carbonate (Piper 1966), soil organic carbon (Walkley and Black 1934), pH, electrical conductivity, cation exchange capacity (CEC), exchangeable bases $\left(\mathrm{Ca}^{2+}, \mathrm{Mg}^{2+}, \mathrm{Na}^{+}\right.$and $\left.\mathrm{K}^{+}\right)$(Jackson 1973). On the basis of morphological, physical and chemical properties, soils were classified as per the Keys to Soil Taxonomy (Soil Survey Staff 2014). Soil map at phase level was delineated on 1: 10000 scale in ARCGIS 10.5 software. The soil-site suitability was worked out for pigeonpea, cotton, maize, sugarcane, wheat and chick pea as per the methodology given in the FAO frame work on land evaluation (FAO 1976), modified by Sys et al. (1991) and Naidu et al. (2006).

\section{Results and Discussion}

\section{Morphological Properties}

Three soil series namely Umraj, Derol and Singdot were identified and mapped into five mapping units as phases of soil series. The morphological, physical and chemical characteristics of soils series are presented in table 1 to 3 . The LEUs and representative pedons of soil maps are presented in fig. 2 and 3, respectively and soil mapping units are presented in table 4. Soils of Umraj series were very deep, moderately well drained and occur on nearly level to very gently sloping old alluvial plains. The soils were very dark grey $(10 \mathrm{YR} 3 / 1)$ in colour, clay in texture and had medium weak sub-angular to medium moderate angular blocky structure. These soils had 2-3 cm wide upto $30-40 \mathrm{~cm}$ and slickenside was observed at $40-48 \mathrm{~cm}$ depth. Derol soils were very deep and occur on nearly level to very gently sloping recent alluvial plains. These soils were moderately well drained, very dark greyish brown (10YR3/2) to dark yellowish brown (10YR4/4) in colour, silty clay in texture with medium weak subangular to medium moderate angular blocky structure. Singdot soils were very deep, calcareous, well drained, dark yellowish brown (10YR4/4) in colour, clay loam to loamy in texture with medium weak sub-angular blocky structure and occur on very gently sloping recent alluvial plains 


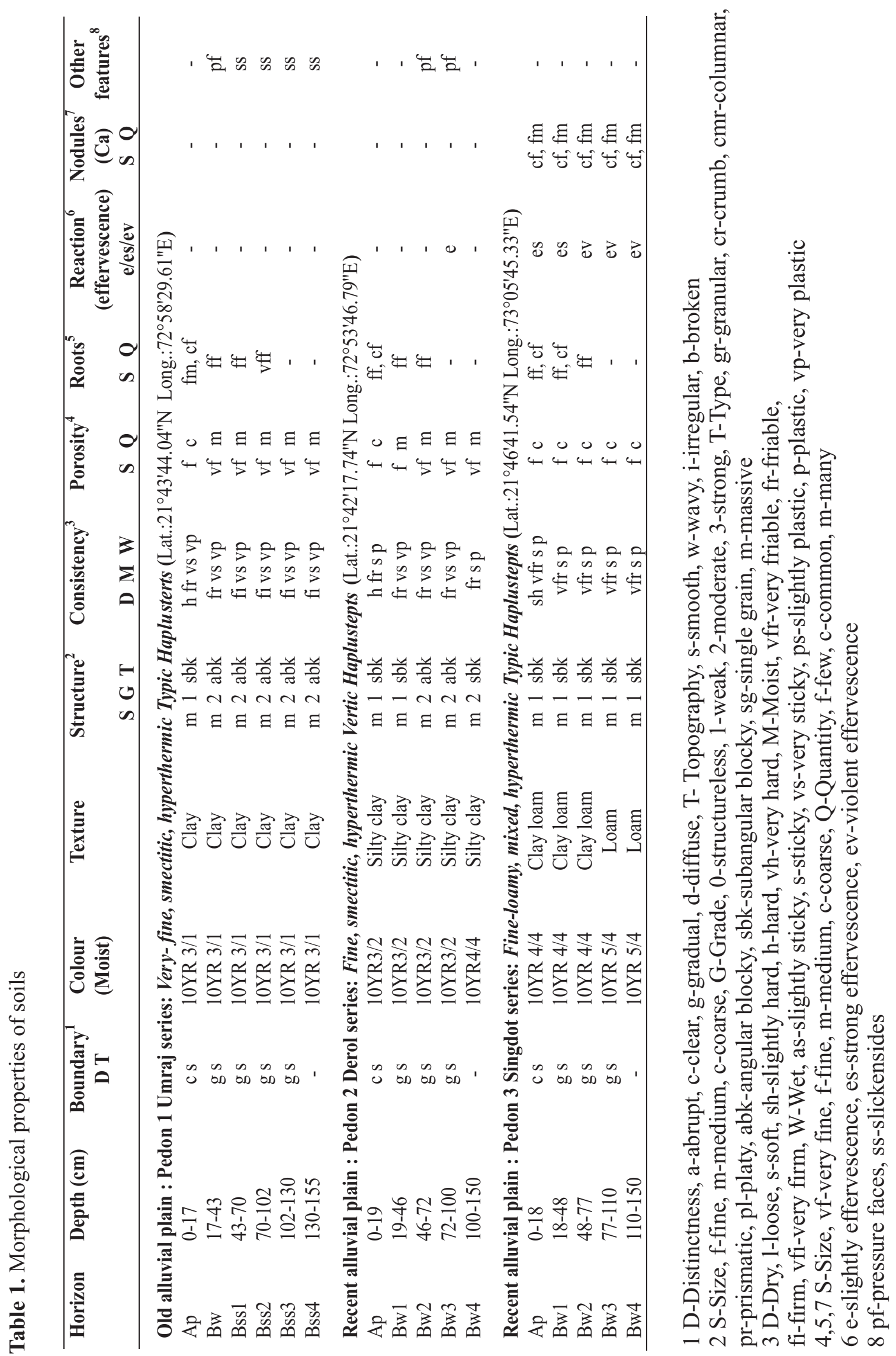




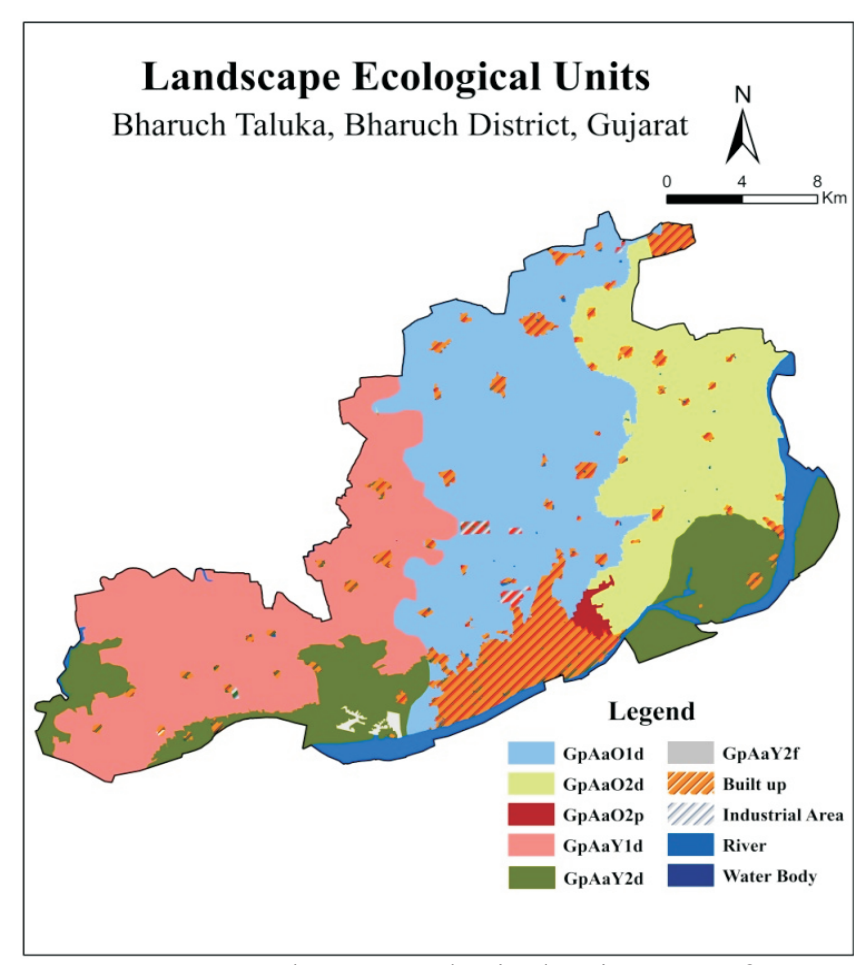

Fig. 2 Landscape ecological units map of Bharuch Taluka

Physical Properties

The data on particle size distribution (Table 2) indicated that the sand content of the soils varied from

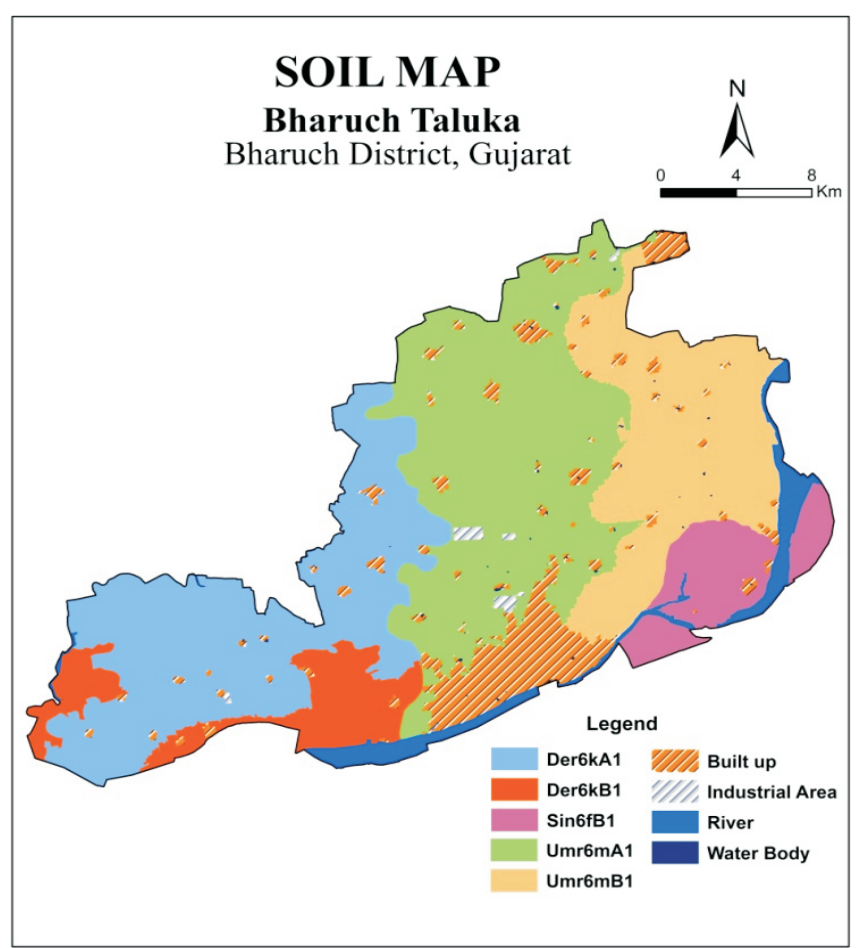

Fig. 3 Soil map of Bharuch taluka

10 to 31 per cent in the surface layer, whereas it varied from 7.8 to 27.7 per cent in the sub-surface layers. Silt content ranged from 24.2 to 49.3 per cent and

Table 2. Physical properties of soils

\begin{tabular}{|c|c|c|c|c|c|}
\hline Horizon & $\begin{array}{l}\text { Depth } \\
\text { (cm) }\end{array}$ & $\begin{array}{r}\text { Sand } \\
<\end{array}$ & $\begin{array}{l}\text { Silt } \\
-(\%)-\end{array}$ & $\begin{array}{l}\text { Clay } \\
->\end{array}$ & $\begin{array}{c}\mathrm{sHC} \\
\left(\mathrm{cm} \mathrm{hr}^{-1}\right)\end{array}$ \\
\hline \multicolumn{6}{|c|}{ Pedon 1 Umraj series: Very-fine, smectitic, hyperthermic Typic Haplusterts } \\
\hline Ap & $0-17$ & 10.0 & 25.8 & 64.2 & 0.10 \\
\hline $\mathrm{Bw}$ & $17-43$ & 7.8 & 26.9 & 65.3 & 0.09 \\
\hline Bss 1 & $43-70$ & 9.2 & 25.1 & 65.7 & 0.08 \\
\hline Bss2 & $70-102$ & 8.5 & 24.9 & 66.6 & 0.07 \\
\hline Bss 3 & $102-130$ & 9.1 & 24.6 & 66.3 & 0.07 \\
\hline Bss 4 & $130-155$ & 8.6 & 24.2 & 67.2 & 0.06 \\
\hline \multicolumn{6}{|c|}{ Pedon 2 Derol series: Fine, smectitic, hyperthermic Vertic Haplustepts } \\
\hline Ap & $0-19$ & 16.2 & 41.5 & 42.3 & 0.16 \\
\hline Bw1 & $19-46$ & 16.8 & 40.2 & 43.0 & 0.32 \\
\hline Bw2 & $46-72$ & 15.5 & 40.7 & 43.8 & 0.62 \\
\hline Bw3 & $72-100$ & 14.2 & 40.9 & 44.7 & 0.79 \\
\hline $\mathrm{Bw} 4$ & $100-150$ & 14.3 & 40.7 & 45.0 & 0.77 \\
\hline \multicolumn{6}{|c|}{ Pedon 3 Singdot series: Fine-loamy, mixed, hyperthermic Typic Haplustepts } \\
\hline Ap & $0-18$ & 31.0 & 38.6 & 30.4 & 1.60 \\
\hline Bw1 & $18-48$ & 23.7 & 41.2 & 35.1 & 1.29 \\
\hline Bw2 & $48-77$ & 23.5 & 45.8 & 30.7 & 2.00 \\
\hline Bw3 & $77-110$ & 27.4 & 49.3 & 23.3 & 1.82 \\
\hline $\mathrm{Bw} 4$ & $110-150$ & 27.7 & 47.8 & 24.5 & 1.86 \\
\hline
\end{tabular}


decreased with depth except in Singdot series. The clay content of the soils varied from 30.4 to 64.2 per cent in the surface horizons whereas it varied from 23.3 to 67.2 per cent in the sub-surface horizons. The total clay content increased with depth in Umraj and Derol series, whereas it was irregularly distributed in Singdot series. The increase in clay content in pedons with soil depth indicated illuviation of clay from surface to sub-surface horizons of Derol soils (Bhattacharyya et al. 1998). Saturated hydraulic conductivity was very slow $\left(<0.1 \mathrm{~cm} \mathrm{hr}^{-1}\right)$ in soils of Umraj series, slow to moderately slow (0.16-0.79 cm $\left.\mathrm{hr}^{-1}\right)$ in Derol series and moderately slow $(1.29-2.0 \mathrm{~cm}$ $\mathrm{hr}^{-1}$ ) in Singdot series (Table 2). It might be due to variability in particle size distribution, exchangeable sodium percentage, $\mathrm{pH}$ and organic matter.

\section{Chemical Characteristics}

In general, the surface soils were neutral to slightly alkaline in reaction with $\mathrm{pH}$ ranging from 7.3 to 8.3. The sub-surface soils were slightly alkaline ( $\mathrm{pH}$ 7.6-8.4) in nature (Table 3). The electrical conductivity ranged from 0.10 to $1.07 \mathrm{dS} \mathrm{m}^{-1}$. The organic carbon content was low and ranged from 0.14 to 0.43 per cent except in Ap horizon of Umraj soils $(0.58 \%)$. The calcium carbonate $\left(\mathrm{CaCO}_{3}\right)$ content ranged from 1.9 to 16.5 per cent and it increased with depth in all the soils, which may be due to calcification under alkaline soil environment (Srivastava et al. 2002) and highest $\mathrm{CaCO}_{3}$ was found in Singdot soils (9.2- $16.5 \%$ ). The cation exchange capacity (CEC) and base saturation per cent (BSP) ranged from 39.4 to $62 \mathrm{cmol}\left(\mathrm{p}^{+}\right) \mathrm{kg}^{-1}$ and from 67.4 to 92 per cent, respectively (Table 3). $\mathrm{Ca}^{2+}$ and $\mathrm{Mg}^{2+}$ were the dominant cations followed by $\mathrm{Na}^{+}$and $\mathrm{K}^{+}$. The ratio between $\mathrm{Ca}$ and $\mathrm{Mg}$ (Ca:Mg) varied from 1.3 to 6.1 and narrower $\mathrm{Ca}: \mathrm{Mg}$ ratio was due to the chemical composition and nature of parent materials from which soils had been derived. The exchangeable sodium percentage (ESP) and exchangeable magnesium percentage (EMP) ranged from 0.5 to 13.3 per cent and 11.3 to 30.4 per cent, respectively (Table 3). The continued removal of $\mathrm{Ca}^{2+}$ as $\mathrm{CaCO}_{3}$ in the prevailing semi-arid climate may adversely cause development of sub-soil sodicity that may affect the use and management of these soils in future (Chinchmalatpure et al. 2008). Derol soils had high ESP in surface layer due to accumulation of sodium salt by frequent irrigations and subsequent evapotranspiration coupled with heavy application of fertilizers. High EMP in the soils indicates the presence of Mg-rich minerals such as palygorskite and dolerite, which are found in the marine and alluvial deposited soils of Gujarat coastal plains (Vasu etal. 2018).

\section{Soil Classification}

Umraj soils with slickensides close enough to intersect, cracks (2-3 cm wide upto 30-40 cm deep) and more than 30 per cent clay in all the horizons, were classified as Vertisols. These soils were placed under Typic Haplusterts at subgroup level on the basis of Ustic soil moisture regime (SMR) and absence of lithic contact within $50 \mathrm{~cm}$ depth from the surface. These soils were very deep, clay in texture (67.2 per cent) and thus classified under very-fine family textural class.

Derol and Singdot soils have cambic $(\mathrm{Bw})$ sub-surface diagnostic horizon and were classified as Inceptisols. Both soils were grouped under Ustepts at sub-order level due to 'Ustic SMR and Haplustepts at the great group level because these pedons did not show either duripan or calcic horizon and base saturation was more than 60 per cent at a depth between 25 to $75 \mathrm{~cm}$ from the surface. Derol soils were placed under Vertic Haplustepts due to shrink- 


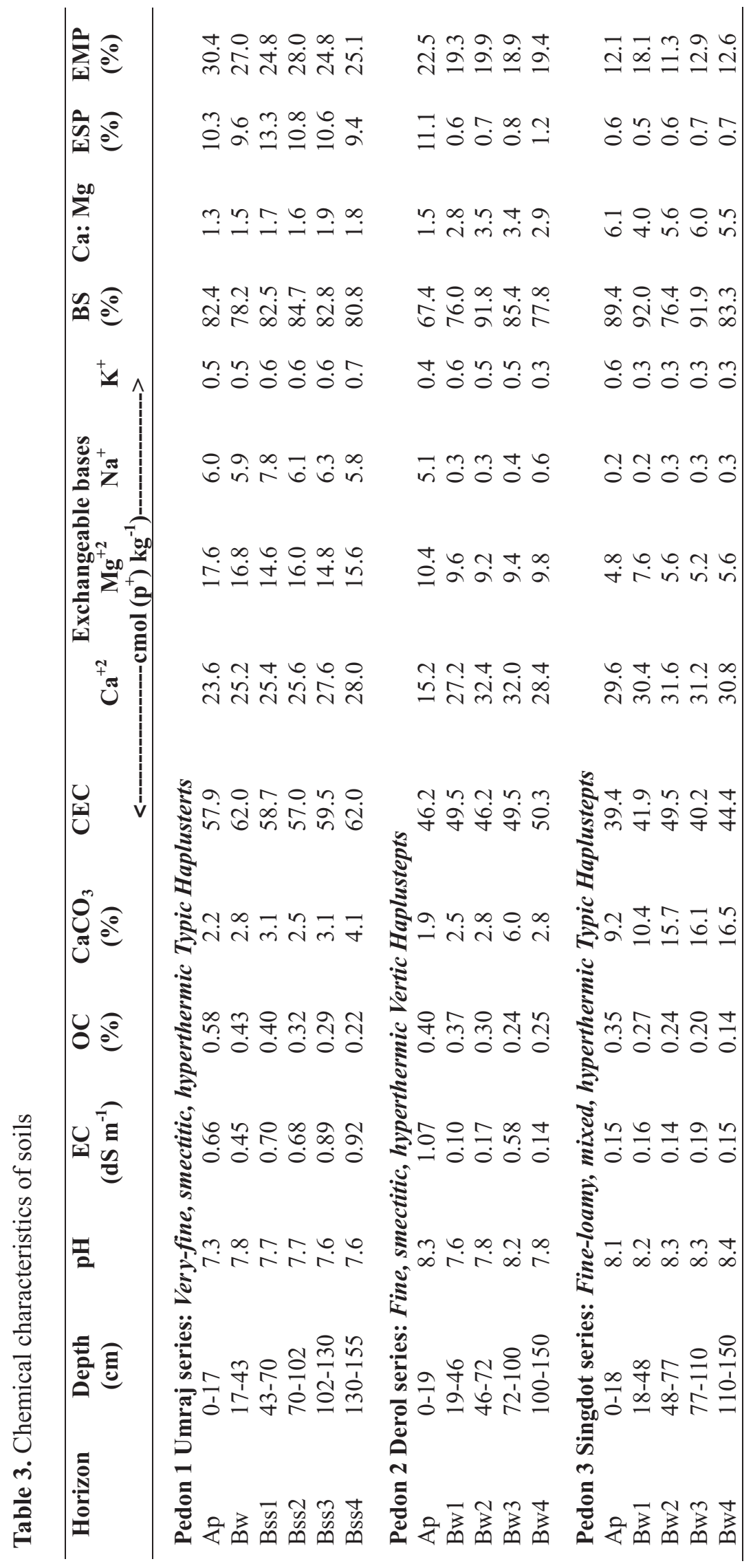




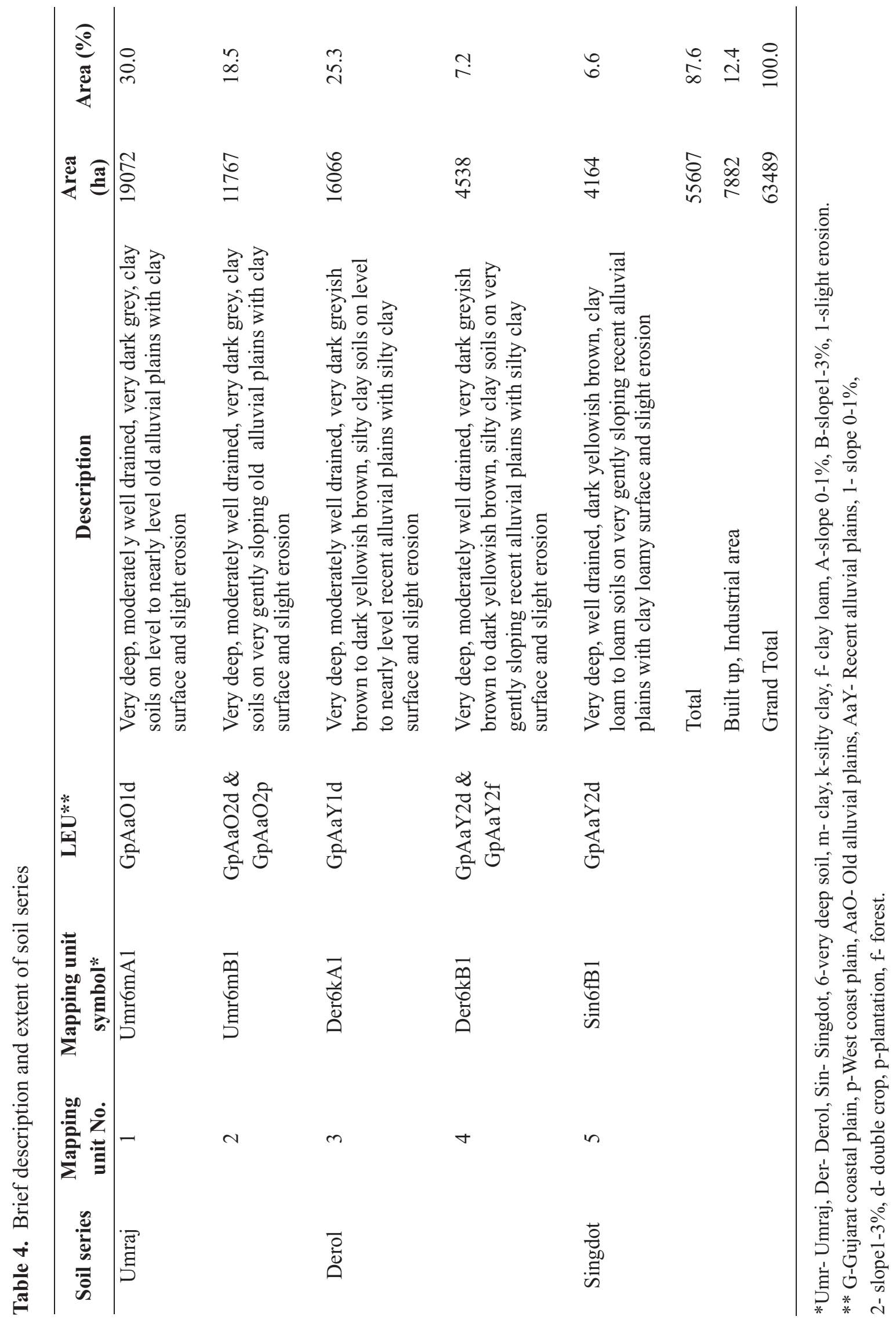


swell properties and presence of pressure faces between 46 to $100 \mathrm{~cm}$ depth and having 42 to 45 per cent clay content. Derol soils were very deep, silty clay in texture with 42-45 per cent clay content and thus qualify for having fine family textural class. Singdot soils did not have lithic contact within $50 \mathrm{~cm}$ depth therefore, grouped under Typic Haplustepts. These soils were also very deep, clay loam to loam in texture with clay content up to 35 per cent and classified as fine-loamy, textural family class.

\section{Soil Suitability for Crops}

According to suitability assessment criteria proposed by Sys et al. (1991) and Naidu et al. (2006), soil site suitability of all the mapping units was assessed for major crops grown in the area. The majority of soils were assessed as highly suitable (S1) to moderately suitable (S2) for the major crops (Table 5 ). Out of the five mapping units, four units (1 to 4) comprised of 51,443 ha area was highly suitable for cotton cultivation and moderately suitable for other major crops (pigeon pea, maize, sugarcane, wheat and chick pea). LGP, drainage and texture of these soils are the major constraint for cultivation of pigeon pea and maize. For sugarcane and chick pea cultivation, major limitations are mean temperature, rainfall, drainage and texture of these soils. The mapping unit no. 5 (4,164 ha) was highly suitable (S1) for pigeon pea, maize, sugarcane and chickpea whereas moderately suitable (S2) for cotton and wheat crops. Major limitations that decide the suitability of these soils for cotton and wheat cultivation are LGP, drainage and texture of the soils. The cultivation of these crops as per their suitability of soils can support the sustainable crop production without any adverse impact in soils of Bharuch taluka.

\section{Summary}

Based on soil survey, three soil series were identified in Bharuch taluka of district Bharuch, Gujarat. Vertisols occupy $48.5 \%$ and Inceptisols 39.1 $\%$. Soils were mostly clay to silty clay in texture, neutral to slightly alkaline in reaction, low to medium organic carbon content and medium to high in cation exchange capacity [39.4- $\left.62.0 \mathrm{cmol}(\mathrm{p}+) \mathrm{kg}^{-1}\right]$ with high base saturation (67.4-92.0\%). Soils were highly suitable cotton and moderately suitable for pigeonpea, maize, sugarcane, wheat and chickpea. Major limitations that decide the suitability of these soils are rainfall, mean temperature, LGP, drainage and texture of the soils. Hence, proper soil and water conservation measures as well as good agronomic practices may be adopted to enhance productivity.

Table 5. Soil Suitability for major crops

\begin{tabular}{ccccccc}
\hline $\begin{array}{c}\text { Mapping } \\
\text { unit no. }\end{array}$ & Cotton & Pigeon pea & Maize & Sugarcane & Wheat & Chick pea \\
\hline 1 & $\mathrm{~S} 1$ & $\mathrm{~S} 2$ & $\mathrm{~S} 2$ & $\mathrm{~S} 2$ & $\mathrm{~S} 2$ & $\mathrm{~S} 2$ \\
2 & $\mathrm{~S} 1$ & $\mathrm{~S} 2$ & $\mathrm{~S} 2$ & $\mathrm{~S} 2$ & $\mathrm{~S} 2$ & $\mathrm{~S} 2$ \\
3 & $\mathrm{~S} 1$ & $\mathrm{~S} 2$ & $\mathrm{~S} 2$ & $\mathrm{~S} 2$ & $\mathrm{~S} 2$ & $\mathrm{~S} 2$ \\
4 & $\mathrm{~S} 1$ & $\mathrm{~S} 2$ & $\mathrm{~S} 2$ & $\mathrm{~S} 2$ & $\mathrm{~S} 2$ & $\mathrm{~S} 2$ \\
5 & $\mathrm{~S} 2$ & $\mathrm{~S} 1$ & $\mathrm{~S} 1$ & $\mathrm{~S} 1$ & $\mathrm{~S} 2$ & $\mathrm{~S} 1$ \\
\hline
\end{tabular}




\section{References}

Akpan-Idiok, A. U., Enya, C. N. and Ofem, K. I. (2016). Characterization and sustainability of basaltic soils supporting cocoa in Ikom, Southeast Nigeria. African Journal of Agricultural Science and Technology 4, 762770.

Bhattacharyya, T., Mukhopadhyoy, S., Buruah, U. and Chamuah, G. S. (1998). Need of soil study to determine degradation and landscape stability. Current Science 74, 42-47.

Chinchmalatpure, A. R., Khandelwal, M. K. and Rao, G. G. (2008). Characterization and classification of salt affected soils of Samni farm, Bharuch district, Gujarat. Agropedology $18,71-75$.

FAO (1976). A framework on Land Evaluation, Soils Bulletin 32, FAO, Rome.

Hossain, M. S., Hossain, A., Sarkar, M. A. R., Jahiruddin, M., Silva, J. A. T. D. and Hossain, M. I. (2016). Productivity and soil fertility of the rice-wheat system in the high Ganges river floodplain of Bangladesh as influenced by the inclusion of legumes and manure. Agriculture, Ecosystems and Environment 218, 40-52.

Jackson, M. L. (1973). Soil Chemical Analysis. Prentice Hall of India (Pvt.) Ltd., New Delhi.

Jackson, M. L. (1979). Soil Chemical AnalysisAdvanced Course. Second Edition (University of Wisconsin, Madison.).

Jagdish Prasad, Ray, S. K., Gajbhiye, K. S. and Singh, S. R. (2009). Soils of Selsura research farm in Wardha district, Maharashtra and their suitability for crops. Agropedology 19, 84-91.

Klute, A. (1965). Laboratory measurement of hydraulic conductivity of saturated soil. In 'Methods of Soil Analysis: Part 1. Physical and mineralogical properties, including statistics of measurement and sampling'. (Eds. C. A. Black) pp. 210-221. (American Society of Agronomy, Madison, USA)
Manchanda, M. L., Kudrat, M. and Tiwari, A. K. (2002). Soil survey and mapping using remote sensing. Tropical Ecology 43, 61-74.

Merh, S. S. (1995). Geology of Gujarat. (Bangalore: Geological Society of India).

Naidu, L. G. K., Ramamurthy, V., Challa, O., Hegde, R. and Krishnan, P. (2006). Manual soil-site suitability criteria for major crops. National Bureau of Soil Survey and Land Use Planning, Technical Publication No. 129, Nagpur.

Piper, C. S. (1966). Soil and Plant Analysis. Hans Publishers, Bombay.

Sharma, R. P., Singh, R. S., Singh, S. K. and Arora, S. (2018). Land resource inventory (LRI) for development of sustainable agricultural land use plans using geospatial techniques: A case study of Pata Meghpar village, Jamnagar district, Gujarat. Journal of Soil and Water Conservation 17, 15-24.

Singh, S. K., Chatterji, S., Chatteraj, S. and Butte, P. S. (2016). Land resource inventory (LRI) on 1:10000 scale, Why and How? Technical Publication No. 172. ICAR-National Bureau of Soil Survey and Land Use Planning, Nagpur, India.

Srivastava, P., Bhattacharyya, T. and Pal, D. K. (2002). Significance of the formation of calcium carbonate minerals in the pedogenesis and management of cracking clay soils (Vertisols) of India. Clays and Clay Minerals 50, 111-126.

Soil Survey Staff (2014). 'Keys to Soil Taxanomy'. Twelth Edition, (Natural Resources Conservation Service, USDA Washington, DC).

Sys, C. E., Van, R. and Debayeve, J. (1991). Land Evaluation, Part I and II. Re-edited volumes of Publication No. 7, (General Administration of Cooperation and Development, Brussels, Belgium).

Vasu, D., Tiwari, G., Jangir, A., Dash, B., Tiwari, P. and Chandran, P. (2018). Poor hydraulic 
conductivity of magnesium rich Alfisols occurring in south Gujarat coastal plains. $21^{\text {st }}$ Annual Convention of CMSI \& National Conference on "Advances in Clay Science Towards Agriculture, Environment and Industry", pp.18.
Velayutham, M., Mandal, D. K., Mandal, C. and Sehgal, J. (1999). Agro-ecological subregions of India for planning and development. Nagpur, India. NBSSLUP Publ. 35, 372.

Walkley, A. and Black, I. A. (1934). An examination of the Degtjareff method for determining soil organic matter and a proposed modification of the chromic acid titration method. Soil Science 37, 29-38.

Received: August, 2018 Accepted: December, 2018 